\title{
Parathyroid Adenomas in Adults and Adolescents. Critical Appraisal and Surgical Strategy in 18 Cases
}

\author{
${ }^{1} \mathrm{~V}^{\text {th }}$ Surgical Department; ${ }^{2} \mathrm{~V}^{\text {th }}$ Pediatric Department \\ Grigore T Popa University of Medicine and Pharmacy Iași, Romania
}

Mihai Radu Diaconescu', Ioan Costea', Mihai Glod', Radu Terinte', Smaranda Diaconescu ${ }^{2}$

Corresponding author:

Mihai Glod MD

1, G. Ibraileanu street, 700506 lași Romania

E-mail:mihai-glod@yahoo.com
Received: 9.11.2016 Accepted: 1.02.2017

\section{Rezumat \\ Adenoamele paratiroidiene la adulți și adolescenți. Evaluare clinică și strategie chirurgicală în 18 cazuri}

Introducere: Studiul nostru subliniazã raritatea cazurilor de adenoame paratiroidiene (AP) publicate în literatura medicalã autohtonã, expresia clinicã diferitã în care predominã formele "istorice" ale bolii ca şi dificultãțile şi întârzierile de diagnostic confirmând totodatã chirurgia ca standardul de aur al tratamentului.

Pacienți şi metodã: Sunt analizate retrospectiv demografia, datele clinice, de laborator şi cele imagistice, procedurile chirurgicale şi constatãrile anatomopatologice ca şi rezultatele obținute în 18 cazuri documentate de AP tratate chirurgical.

Rezultate: Raportul m/f al cazurilor a fost de 1/5 iar vârsta acestora a variat între 16-58 (medie 46). Litiaza urinarã $(n=9)$ şi leziunile osoase $(n=6)$ au fost cele mai întâlnite manifestãri menționate. Acestora li s-au adãugat tulburãri psihiatrice şi neuromusculare, cele digestive (pancreatita şi ulcerul peptic), hipertensiune arterialã ca şi prezența unui nodul palpabil. Diagnosticul a fost confirmat prin dozãrile calciului şi fosforului seric, fosfatazei alcaline şi PTH, ecografia şi scintigrafia cu technețiu $99 \mathrm{~m}$. Au fost practicate 18 adenomectomii din care 16 dupã explorarea cervicalã bilateralã şi douã prin abord minim invaziv. In 9 situații s-a recurs la exereze tiroidiene concomitente pentru leziuni asociate sau în scop tactic. Examenul microscopic a confirmat diagnosticul de AP cu celule principale şi oxifile, într-un caz fiind identificat un adenom "atipic". Într-o altã observație, la 3 ani dupã exereza unui AP benign, s-a constatat o recidivã clinicã ipsilateralã care s-a dovedit a fi un carcinom (leziune nouã sau eroare a diagnosticului inițial?). Evoluția clinicã şi bioumoralã postoperatorie imediatã şi la distanțã a fost favorabilã în toate cazurile cu excepția cazului de carcinom care a decedat dupã 14 luni de la reintervenție.

Concluzii: În pofida raritãții şi dificultãților de diagnostic a cazurilor de AP, practicienii trebuie sã fie conştienți de posibilitatea existenți acestor leziuni în vederea unui tratament cât mai precoce şi adecvat în care chirurgia reprezintã standardul de aur. 
Cuvinte cheie: adenom paratiroidian, chirurgie, standard de aur

\begin{abstract}
Background: Our study underline scarcity of isolated case reports or small case series of parathyroid adenoma (PA) published in autochthonous medical literature,their variable clinical expression among the "historic" varieties but also the diagnostic difficulties and delays of diagnosis as well consecration of surgery as the golden therapeutic standard of this disorder.

Patients and Method: Demographic, clinical presentations, laboratory and imaging data, operative findings and procedures together with pathology account and outcome from the case reports of 18 patients with documented PHP were retrospectively analyzed.

Results: The male/female ratio was $1 / 5$, with ages ranging from 16 to 58 (mean 46) years. Renal stones (n=9) and bone sufferings $(n=6)$ were the most common modes of presentation. To these were added psychiatric and neuromuscular complaints, digestive disorders (pancreatitis and peptic ulcer) arterial hypertension and presence of a palpable nodule. Mean serum calcium and phospho-rus, alkaline phosphatase and PTH dosage together with parathyroid ultrasound and $99 \mathrm{~m}$ Tc sestamibi scintigraphy are the most useful parameters for diagnosis. Eighteen adenomectomies were performed of which bilateral neck exploration was done in 16 patients and minimally invasive approach in the remaining two cases. In 9 situations concomitant thyroid exeresis for associated lesions or tactical purpose were done. Pathology revealed single adenoma consisting of main and oxyphil cells in 17 cases. In one case an atypical adenoma was identified and in another case three years after removal of a benign adenoma the subject presented a clinical ipsilateral recurrence which provided to be a carcinoma. Postoperative clinical and humoral outcome was favorable in all situations less the case of carcinoma which died after 14 months.

Conclusions: Despite the rarity and difficulties of diagnosis in cases of PA, practitioners must be aware of potential existence of these lesions in order to apply as early and appropriate treatment where surgery is the gold standard.
\end{abstract}

Key words: parathyroid adenoma, surgery, gold standard

\section{Introduction}

Primary hyperparathyroidism (PHP) is the third most common endocrine disorder after diabetes mellitus and thyroid illnesses, the case studies showing an estimated prevalence in general population of $0,5-1 \%$ and an annual incidence of 28 cases per 100000 people $(1,2,3)$. Single gland sporadic parathyroid adenoma (PA) represents the most frequent cause $(85-90 \%)$ of PHP cases.

In the other affected patients hyperplasia, carcinoma and familial forms can occur $(4,5)$. Demographics and clinical characteristics of PA underwent a dramatic change in the 1970s with the widespread availability of serum calcium screening by the multichannel autoanalyzer $(6,7)$. Therefore the rare classical observations of PA diagnosed by consecrated clinical tetrad "painful bones, renal stones, abdominal groans and psychic moans" and objectification of hipercalcemia, become actually a common endocrine disease, $80 \%$ of cases appearing asymptomatic at diagnosis and often having mild hypercalcemia $(8,9)$. However in our country the number of operated cases and publications about this pathology is still limited to few practitioners in some specialized units (10-20).

\section{Patients and Method}

Eighteen cases with confirmed clinical, biological and histological diagnosis of PA operated on within a period of three decades in our clinic were retrospectively analysed. In our series we registered 15 females and 3 males with a female/male ratio of $5 / 1$, and an average age of 46 years (range16-58) years. There was no statistically significant difference in the frequency of clinical manifestations between males and females.

Demographic data, clinical presentation, preoperative biochemical and hormonal findings, localization imaging, operative findings and techniques, postoperative outcome, histopathological reports, immediate and long-term status were also assessed. All the patients underwent surgery. Bilateral neck exploration was performed in 16 cases and two minimally invasive adenomectomy were also done.

Statistical analysis was performed with Student's t test and with Mann Whitney U test. The mean results and standard deviation was given. A P value less than 0,05 was considered to be significant. 


\section{Results}

Except one case appearing as familial PHP (a sister operated on for PA) all our observations were considered as sporadic. We encountered only cases of solitary adenoma even if in our experience we also founded two cases of parathyroid carcinoma. Outside only one asymptomatic observation incidentally discovered during thyroidectomy for a simple multinodular goiter, the rest of the 17 cases of PA presented a polymorphic "florid" simptomatology interesting many of body systems and apparatus sometimes difficult to interpret which has led to some delays or errors in diagnosis and hesitations of treatment.

The analysis and hierarchy of different anatomic or functional features led them together in major syndromes that dominated clinical scene.

Neuropsychiatric troubles $(n=5)$ were present as depressive phenomena of psychasthenic type, mental slowness and also one case of sudden confusion syndrome appearing after urologic surgery. Varying degrees of asthenia, somnolence or fronto-occipital cephalalgia added in some cases. In 8 patients myasthenia intricate with osteoarticular pains.

Main clinical circumstances and surgical selection in our cases occurred through bone manifestations $(n=6)$, those of urolithiasis $(n=9)$ or pancreatic acute sufferings $(n=2)$.

Bone and joint disorders demonstrated by current clinical and radiological examinations included joint pains, subperiostal resorbtion, systemic osteopenia, osteitis fibrosa cystica, bone calcifications, cyst or geodes and sequels of pathological fractures fracture sequelae (Fig. 1).

Urolithiasis was the most common feature encountered in PA often being the alarm signal of disease presenting itself as multiple or bilateral $(n=4)$ and recurrent $(n=5)$ forms, associated with hematuria and infection produced by E coli, proteus with often tenacious resistance to chimiotherapy and renal dysfunction. Urinary stones were diagnosed, sometimes incidentally, by ultrasound, standard X-ray exams or urography (Fig. 2).

Before or rarely after PA surgery specific urolithiasis treatment was done performing urethero- or pyelotomies in 8 cases, one observation benefiting from a lithotripsy. In six patients iterative urologic surgery was necessary: A 52-year old man underwent in 1966 a gastrectomy for perforated duodenal peptic ulcer and 5 years later surgical debridement and drainage for acute necrotizing pancreatitis was done. After ward he experienced a numberless advents of multiple, bilaterally recurrent urinary tract stones resorting to 10(!) pyelo- and/or uretherolithotomies. Finally a huge left coral form stone imposed a nephrectomy. Twenty years then addressing to our unit he presented a $2 \mathrm{~cm} \varnothing$ irregular calculus in the remaining right kidney associated with chronic renal failure (BUN=75-138 $\mathrm{mg} / \mathrm{dL}$, creatinine $=2,8-4,3 \mathrm{mg} / \mathrm{dL}$ ) also accusing asthenia, osteoarticular pains, edema and pruritus. Serum calcium was $12 \mathrm{mg} / \mathrm{dL}, \mathrm{AF}=49 \mathrm{IU}$ and $\mathrm{iPTH}$ $=290 \mathrm{pg} / \mathrm{mL}$. Ultrasound revealed a $1,8 \mathrm{~cm} \varnothing$ round, hypoechoic, well-circumscribed left cervical nodule. At cervicotomy we discovered a left sided adenoma of $1,7 \times 1,0 \times 0,7 \mathrm{~cm}$ weighting $6 \mathrm{gm}$. Pathology confirmed the diagnosis of parathyroid cell adenoma. Postoperative evolution was normal the patient being directed for a qualified lithotripsy. At 1-5 years follow-up he was in good clinical and humoral condition. We noted retrospectlvely in his sagacious medical history two sisters with urolithiasis one of them also operated for PA (18).

Arterial hypertension observed In 5 patients as minor EKG changes had rather an essential character (18).

Paramedian cervical swelling with small volume

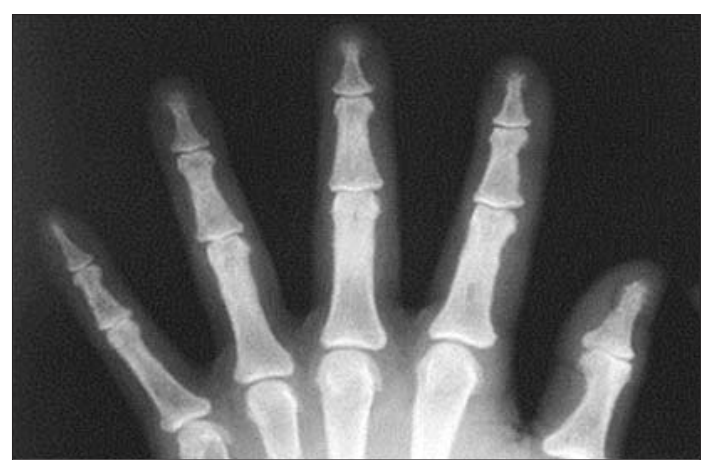

Figure 1. Subperiostal phalangeal resorbtion

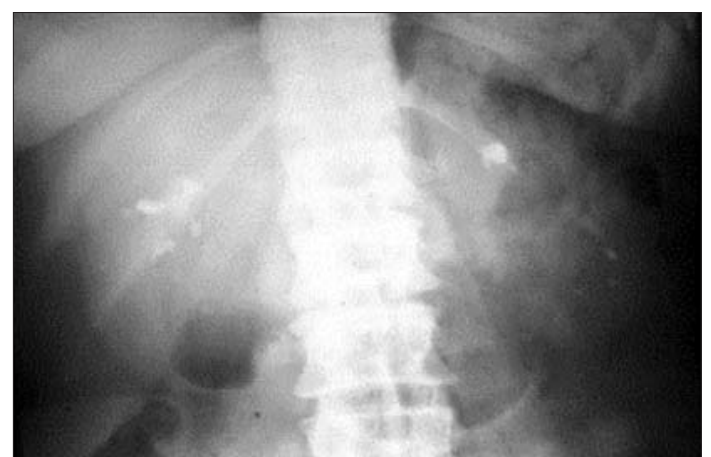

Figure 2. Multiple, bilateral urinary stones 
of $1-1,5 \mathrm{~cm} \varnothing$ suggesting a parathyroid adenoma was found in only 5 cases while coexistence with an

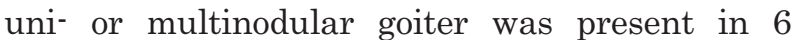
patients (four of them coming from endemic areas). We also mention various other symptoms as palpebral congestion, ectopic calcifications or pseudogout.

Laboratory tests and complimentary imaging localization tools was the major elements that defined functional diagnosis of PA.

Biochemical parameters in our series documented hypercalcemia (mean values $=3,08+-0,25 \mathrm{mmol} / \mathrm{L}$ ) in all patients even the asymptomatic one.

Hypophosphatemia (mean values 1+-0,2 $\mathrm{mmol} / \mathrm{L}$ ) was present in 13 patients. Also mean value serum alkaline phosphatase was higher than normal values in 12 patients (mean values $230=-40$ UI/L). Serum iPTH was elevate in all 12 cases in whom it was available ranging between 127-778 pg/mL Therefore second- and third-generation PTH assays also becomes compulsory of diagnostic algorithm.

The initial preoperative evaluation of the hyperfunctioning culprit was considered vitally important prior to definite its surgical management of. High resolution ultrasound and $99 \mathrm{~m}$ Tc sestamibi scan was practiced objectifying the presence, topography and dimensions of PA together with any associate thyroid pathology. US also accurately inventoried the presence of coexistent thyroid processes. Single photon emission computed scintigraphy (SPECT), $\mathrm{CT}$ and MRI recommended by many authors as current imaging techniques for preoperative localization were not utilized.

\section{Management}

Literature data as well as our modest personal experience attest surgery as the gold standard in the management of these lesions. Formal indica- tions of the method include cases that manifest overt bone or urinary symptoms, severe morbid associations and important biochemical markers (elevated serum calcium and/or PTH) but for some authors surgery was also indicated in so-called "chemical" and/ or asymptomatic forms. In these conditions in 17 of our cases surgery was formally recommended by coexistence of clinical data, laboratory findings (sometimes incomplete) and finally elements pro- vided by ultrasound and in last years 99m Tc sestamibi scintigraphy (Figs. 3 and 4).

All patients had preoperative and postoperative vocal cord assessment. Of the 18 patients the procedure was accomplished under cervical blockade in 5 but in the rest 13 cases general anesthesia was preferred.

Sixteen cases underwent classical approach with collar incision more or less stretched depending clinical or imaging data. To these added two videoassisted minimally-assisted surgeries (Figs. 5 and 6).

Both techniques proceeded to a first assessment of preoperative ascertainments concerning location items providing more or less facile identification of the lesion by topographical and macroscopic criteria of color and volume.

In 9 cases with associated macroscopic thyroid pathology or lack of concordance between preoperative imaging and surgical findings encountering difficulties in the recognition of culprit lesion a wide exploration of bilateral entire parathyroid system was necessary. Thus three patients each under-went subtotal thyroidectomy respectively lobectomy for multinodular benign goiter. In another two cases atypical excision of thyroid tissue was done together with PA located more or less deeply in a small crater or even inside of the thyroid lobe, removal growth also requiring sacrifice of host parenchymal tissue. Finally for tactical purpose one PA located retropharyngeal impose deliberated thyroid sacrifice.

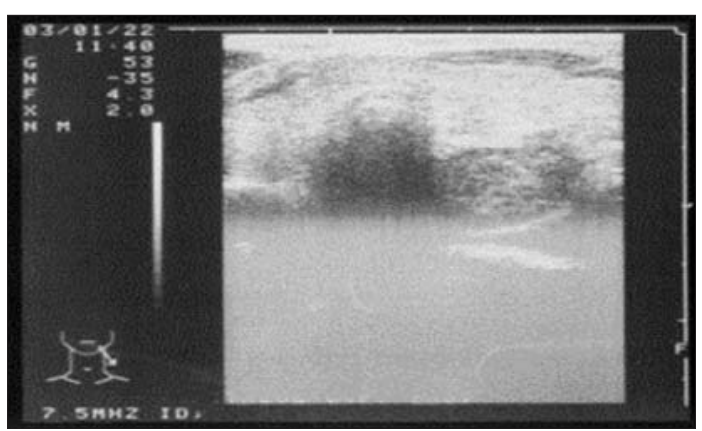

Figure 3. Ultrasound of al left parathyroid adenoma

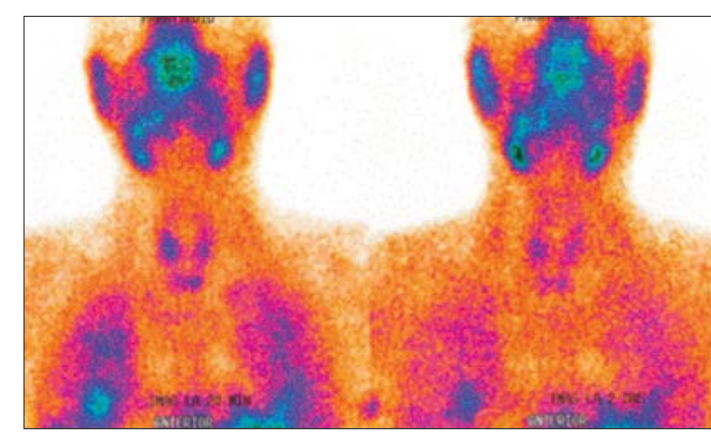

Figure 4. 99m Tc sestamibi scan of parathyroid adenoma 


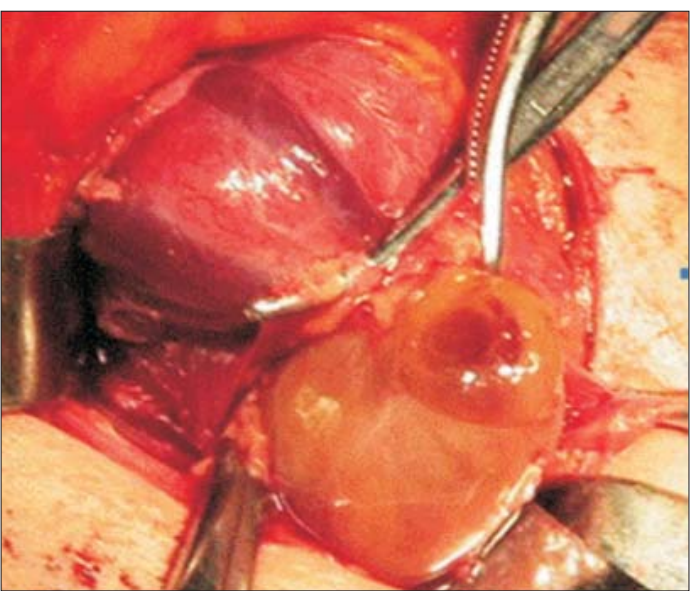

Figure 5. Simple open excision of PA

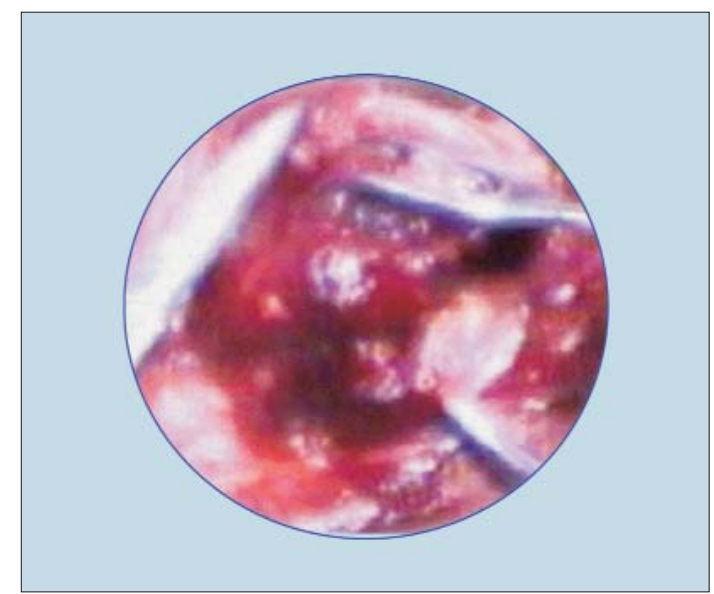

Figure 6. Minimally invasive removal of PA
A particular situation we faced in a 45 year-old female presented with a clinical and biological recurrence after removal of a right sided PA performed elsewhere 3 1/2 years ago. Beside reappearance of functional features 6 months ago she present a round, irregular hypoechogenic lesion of $1,5 \mathrm{~cm} \varnothing$ situated in the same location. Reoperation identified a well-constituted odd firm mass which was en block resected together with ipsilateral thyroid lobe. Paraffin section surprisingly allowed the diagnosis of parathyroid carcinoma (initial histological error or a new lesion ?) but postoperatively the hypercalcemic syndrome recured more severely and she died 14 months later after iterative surgery (17).

In other 9 patients only single adenomectomy (minimally-invasive in two cases) was practiced. After adenoma acknowledgment, lateral retraction of jugular vein and carotid artery, ligation and division of middle thyroid vein with systematic identification of recurrent laryngeal nerve was carried out. Thyroid lobe can then be displaced up and out of its bed, the prominent lesion, being gradually delivered of lax surrounding tissues by gently blunt dissection avoiding rough handling as well as few cuting and hemostatic gestures which can cause capsule breaking and glandular seeding resulting the rare parathyromatosis appearance. Thus complete enucleation preserving the integrity of adenoma capsule was preferred to excision and was possible in all such lesions. Postoperative histopathology showed in 17 patients unique, well circumscribed, homogenous nodules of 0,4-2 cm Ø mainly composed of chief cells and some oxyphil cells with minimal mitotic activity. In one case examination revealed an "atypical" structure of PA with either excess mitotic cells and tumor capsule invasion without trespassing its boundaries and no spontaneous necrosis nor vascular invasion was described. The case had a uneventful postoperative course (Figs. 7 and 8).

Only fourteen observations could be subjected to watchful postoperative follow-up from three months

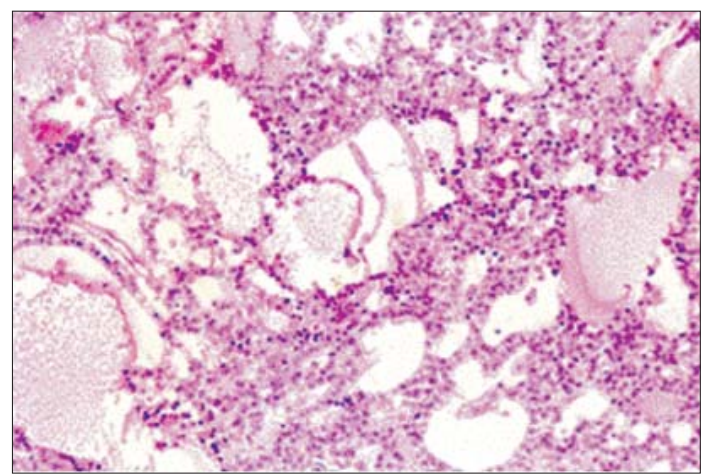

Figure 7. Chief cell parathyroid adenoma Hex200

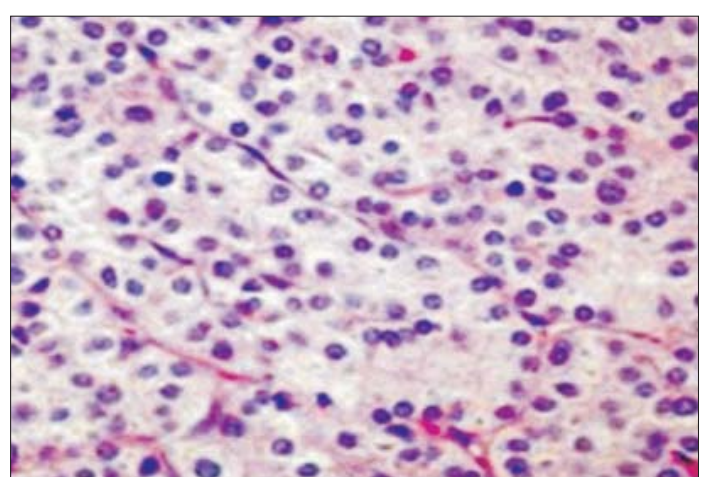

Figure 8. Atypical parathyroid adenoma Hex400 
to three years. We have no mortality or recurrences but morbidity show only two patients with transitory postsurgical symptomatic hypocalcemia requiring intravenous calcium infusion.

All these cases however recovered well after operation. Effects of successful surgery materialized in stable endocrine equilibrium, control of hypercalcemic features through disappearance or at least enhancing of most clinical features and normalization of biological constants, firstly improving of psychic and neuromuscular symptoms i.e. fatigue, depression, lack of concentration or sleep disturbances but also increasing bone density and significant reduction of urolithiasis, resulting for everyone a meaningful improvement in patients QOL. Preexisting arterial hypertension generally not improved.

\section{Discussions and Conclusions}

Current clinical practice guidelines recommend surgery as the main curative approach for most primary hyperparathyroidism patients due in $80 \%$ to a single parathyroid adenoma. Its removal is strongly sustained to correct hypercalcemia and decrease the risk of lesion's complications, especially in patients under 50 years, those with history of osteoporosis or even fractures, urinary stones and low glomerular filtration rate $(21,22)$.

Diagnosis of PHP remain essentially based on laboratory findings of persistent hypercalcemia associated with plasma levels of PTH that are elevated or inappropriately normal together with pre and intraoperative cervical ultrasonography and parathyroid scintigraphy acknowledged as the first-line method used to located pathological parathyroid tissues $(23,24)$.

The number of parathyroidectomies performed worldwide for PA has grown exponentially over the last decades since the advent especially in developed countries of routine testing of blood calcium levels, the greater accuracy and earlier diagnosis of clinically evident but also of asymptomatic or smaller, profound or ectopic located lesions by broad use of well-established modern preoperative imaging and finally by sustained development of less invasive surgical procedures $(25,26)$.

Thereby from classical bilateral four gland exploration of PA an increasing number of unilateral focused minimally invasive techniques have been introduced in numerous centers including open minimal parathyroidectomy but also video-guided, radio-guided and endoscopic removal of $\mathrm{PA}$ with or without rapid intraoperative PTH assay reducing the cost and morbidity while maintaining cure rates $(27,28,29)$.

On the contrary the paucity of patients diagnosed and treated for PA in our country, most of them presenting with delayed, severe metabolic bone and renal disease complaints, is related to lack of systematically calcium screening and therefore the default of awareness of this conditions.

At the same time even if casuistry is reduced, encouraging satisfactory results continuously obtained in our growing experience due to personal concern to endocrine cervical surgery and constantly increasing number of cases operated in time.

By far the most consistent successes were achieved after surgery applied in symptomatic cases - which are majoritarian in Romania as in developing countries - providing most number of patients undergoing parathyroidectomy (17 observations in our series).

Natural history and features of the asymptomatic PA counting only one case in our series revealing modified BMD and bone affecting, mainly neurocognitive complaints and functional cardiovascular abnormalities all improving after parathyroid adenomectomy. However regarding the increasing proportion of unknown asymptomatic patients and the impossibility to predict their evolution the firm indication of parathyroidectomy in these cases must be formulated with more courage (29).

Overall in both symptomatic and asymptomatic cases surgery of PA was safe and effective without mortality but minimal and transient morbidity. Follow-up to three years revealed disappearance or improving of majority of symptoms and clinical signs and normalization of PTH and serum calcium levels.

Our modest experience as main international statistics fail to prove that surgery remain the current definitely gold standard of PA treatment, contributing to an often spectacular remission of most clinical sufferings concomitant with prompt normalization of serum calcium and PTH levels overwise equivalent to their real healing in great majority of cases.

Our work recognized some limitations. Thus the former observations had a random character and were incompletely explored. Also the number of patients, even notable for our country is however reduced and our report includes the shortcomings and biases inherent in a retrospective research. Moreover we did not looked for intervention of avitaminosis D in these conditions.

Further institutional research with larger series 
of cases are desirable.

On the whole numerous studies as our own activity show that surgical treatment shared the same subjective and objective clinical benefits contributing significantly to improve the quality of life (QOL). Concentration in high-volume centers in which this exquisite surgery will be performed only by fully trained practitioners will increase the number and the quality of management of these patients.

\section{References}

1. DeLellis RA, Lloyd RV, Heitz PU, Eng C. World Health Organisation, Classification of Tumours. Pathology and Genetic of Tumours of Endocrine Organs. IARC Press: Lyon; 2004. p. 55

2. Cordellat IM. Hyperparathyroidism: primary or secondary disease? Reumatol Clin. 2012;8(5):287-91.

3. Marcocci C, Saponaro F. Epidemiology, pathogenesis of primary hyperparathyroidism: Current data. Ann Endocrinol (Paris). 2015; 76(2):113-5. doi: 10.1016/j.ando.2015.03.015.

4. Madkhali $\mathrm{T}$ Ahlefdhi $\mathrm{A}$, Chen $\mathrm{H}$, Elfenbein D. Primary hyperparathyroidism. Ulus Cerrahi Derg. 2016;32(1):58-66. doi: 10.5152/UCD. 2015.3032. eCollection 2016.

5. Duan K, Gomez Hernandez K, Mete O. Clinicopathological correlates of hyperparathyroidism. J Clin Pathol. 2015;68(10):771-87. doi: 10.1136 /jclinpath-2015-203186. Epub 2015 Jul 10.

6. Christensson T, Hellstrom K, Wengle B, Alveryd A, Wikland B. Prevalence of hypercalcaemia in a health screening in Stockholm. Acta Med Scand. 1976;200(1-2):131-137.

7. Mundy GR, Cove DH, Fisken R. Primary hyperparathyroidism: changes in the pattern of clinical presentation. Lancet. 1980 21;1(8182):1317-20.

8. Kraimps JL, Barbier J. Aspects cliniques de l'hyperparathyroidisme primaire. In: Barbier J, Henry JF, editoris. L'Hyperparathyroidisme Primaire. Rappott présénté au 93e Congrès Francais de Chirurgie, SpriberVerlag, Paris; 1991. p. 29-38.

9. Shah VN, Bhadada S, Bhansali A, Behera A, Mittal BR. Changes in clinical \& biochemical presentations of primary hyperparathyroidism in India over a period of 20 years. Indian J Med Res. 2014;139(5):694-9.

10. Milcu St, Gottlieb F, Radian N, Ambrozie AM, Angelescu E, Sahleanu V. Over a case of healed parathyroid osteosis. Chirurgia (Bucur). 1955; 4:120.

11. Vexler L, Andrei A, Cordun-Tarabuta G, Pricop L. Parahyroid adenoma in renal lithiasis. Chirurgia (Bucur). 1974;23(1):9-14.

12. Proca E. Relation between primary hyperparathyroidism and renal lithiasis. Chirurgia (Buc). 1983;32(1):1-8.

13. Juvara I, Dragomirescu C, Vereanu I, Radu S. Primary hyperparathyroidism. Diagnosis and treatment difficulties. Chirurgia (Bucur). 1983:32(1):9-20.

14. Strat V, Diaconescu MR, Georgescu St, Popescu E, Zbranca E,
Tiron V, et al: Primary hyperparathyroidism in cystic parathyroid adenoma located in the thyroid. Rev Med Chir (lasi). 1988;92(1): 163-5.

15. Tarcoveanu E, Niculescu D, Moldovanu R, Cotea E, Vasilescu A, Danila N, et al. Surgical treatament of hyperparathyroidism. Chirurgia (Bucur). 2009;105(4):531-44.

16. Diaconescu MR, Vexler L, Costea I, Terinte R, Diaconescu S, Zbranca E, et al. Surgical treatament of parathyroid hyperfunction. Chirurgia (Bucur). 1996;45(6):297-303.

17. Diaconescu MR, Glod M, Costea I, Grigorovici M, Diaconescu S. Clinicopathological phenotype of parathyroid carcinoma: therapeutic and prognostic aftermaths. Chirurgia (Bucur). 2015;110(1):66-71.

18. Diaconescu MR, Glod M, Costea I, Diaconescu S. A diagnosis Odyssey: from acute necrotizing pancreatitis to parathyroid adenoma. Chirurgia (Bucur). 2013;108 Suppl 1:S132-3.

19. Batca V, Jitea N, Albita O, Rogin T, Batca A, Bulata R. Giant parathyroid adenoma with hypersecretion and severe clinical course clinical case. Chirurgia (Bucur). 2011;106(1):113-8.

20. Neagoe RM, Sala DT, Borda A, Mogoanta CA, Muhlfay G. Clinicopathological and therapeutic aspects of giant parathyroid adenomas - three case reports and short review of literature. Rom J Morphol Embriol. 2014;55 Suppl 2:669-74.

21. Mihai R, Barcczynski M, lacobone M, Sitges-Serra A. Surgical strategy for sporadic primary hyperparathyroidism an evidencebased approach to surgical strategy, patient selection, surgical access and reoperations. Langenbecks Arch Surg. 2009;394(5): 785-98.

22. Augustine MM, Bravo DE, Zeiger M. Surgical treatment of primary hyperparathyroidism. Endocr Pract. 2011;17 Suppl 11:75-82.

23. Panzironi G, Falvo V, De Vargas Macciucca M, Vatania A, Sorrenti $R$, Biancafarina $A$, et al. Preoperative evaluation of primary hyperparathyroidism: role of diagnostic imaging. Chir Ital. 2002;54(5): 629-34.

24. Minisola S, Cipriani C, Diacinti D, Tartaglia F, Scillitani A, Pepe J, et al. Imaging of parathyroid glands in primary hyperparathyroidism. Eur J Endocrinol. 2016;174(1):D1-8.

25. Langdahl BL, Ralston SH. Diagnosis and management of primary hyperparathyroidism in Europe. QJM. 2012;105(6):519-25.

26. Jha S, Jayaraman M, Jha A, Jha R, Modi KD, Kelwadee JV. Primary hyperparathyroidism: A changing scenario in India. Indian J Endocrinol. 2016;29(1):80-3.

27. Mourad N, Boumi A, Darius T, Maiter D. Surgical options for primary hyperparathyroidism. Ann Endocrinol (Paris). 2015;76(5): 638-42.

28. Singh Ospina NM, Rodrigues-Gutierrez R, Maraka S, Espinoza de Ycaza AE, Jasim S, Castaneda-Guarderas A, et al. Outcome of parathyroidectomy in patients with primary hyperparathyroidism: a systematic review and meta-analysis.World J Surg. 2016;40(10): 2359-77. doi: 10.1007/s00268-016-3514-1.

29. Bilezikian JP, Brandl ML, Eastell R, Silverberg SJ, Udelsman R, Marcocci $C$ et al. Guidelines for the management of asymptomatic primary hyperparathyroidism: summary statement for the Four International Workshop. J Clin Endocrinol Metab. 2014;99(10): 3561-9. doi: 10.1210/jc.2014-1413. 